European Journal of Accounting, Auditing and Finance Research

Vol.8, No. 7, pp.42-79, July 2020

Published by ECRTD-UK

Print ISSN: 2053-4086(Print), Online ISSN: 2053-4094(Online)

\title{
INVESTOR IRRATIONAL BEHAVIOUR AND ABNORMAL STOCK RETURNS: A CASE OF NAIROBI SECURITIES EXCHANGE
}

\author{
Irene Cherono ${ }^{1}$, \\ Department of Economics, Finance \& Accounting, Jomo Kenyatta University of \\ Agriculture and Technology, Kenya \\ Robert Gitau Muigai ${ }^{2}$, \\ School of Business \& Economics, Kirinyaga University, Kerugoya, Kenya
}

\begin{abstract}
The main objective of the study was to determine the effect of investor behavior on stock returns in Kenya. Specifically, the study determined the effect of herd behavior on stock returns in Kenya; determined the effect of loss aversion on stock returns in Kenya; determined the effect of mental accounting on stock returns in Kenya; and determined the effect of overconfidence on stock returns in Kenya. Empirical studies on the effect of investor behaviour on stock returns are inconclusive especially when it comes to how investor behaviour biases have an effect on returns in Kenya. The target population was 67 listed companies at the Nairobi Securities Exchange. A sample of 48 listed companies was used in the analysis. Secondary data extracted from Nairobi Securities Exchange historical data of listed companies for the period 2004 to 2016 was used in the analysis. The study adopted quantitative research design. The results indicate that investor herd behaviour does not have a significant effect on stock returns. However, investor loss aversion, investor mental accounting and investor overconfidence have significant effect on stock returns in Kenya.
\end{abstract}

KEYWORDS: herd behaviour; loss aversion; overconfidence; mental accounting; stock returns

\section{INTRODUCTION}

As the economic environment is constantly changing and experiencing periods of economic uncertainty, so do the influences on the decision-making process of investors change. Investors fall prey to psychological traps, triggers and misconceptions that lead them to buying and selling at the wrong time leading to underperformance in their investments. The psychological phenomena like fear, greed and misconceptions are perpetuated by investor's limited experience and outside influences holding investors at various points of the market cycle. Tversky and Kahneman (1974) explained that investors would overrate recent information, neglecting or attributing less importance to past news, in their prospects revisions, based on their judgment assessments of probabilities. This would lead to excessive optimism over good news and extreme pessimism over bad news. Stock prices would deviate temporarily from their intrinsic values, originating in the medium-long term, leading to a mean-reverting effect. 
European Journal of Accounting, Auditing and Finance Research

Vol.8, No. 7, pp.42-79, July 2020

Published by ECRTD-UK

Print ISSN: 2053-4086(Print), Online ISSN: 2053-4094(Online)

Stock market overreaction and under-reaction phenomena are inspired by cognitive psychology. It is an important challenge to market efficiency and has helped to build the foundations of behavioral finance. Behavioral finance allows for market inefficiency because market participants are subject to common human errors that arise from heuristics and biases (Ramiah, Xu \& Moosa, 2015). An investor is considered as rational when he keeps getting new information to update his beliefs and makes choices among available alternatives that are acceptable (Thaler, 2005). Past evidences have proved that human beings are inconstant, irrational and incompetent in their decision making under uncertainty. Individuals are not always rational and markets are not always efficient.

Efficient Market Hypothesis states that stocks are rationally priced (Fama, 1970). EMH holds that a stock price accurately reflects full set of available information always such that no one can successfully exploit short-term responses to even extreme price movements. The anomaly of stock price overreaction and under-reaction presents a sufficient challenge to EMH. A common explanation for departures from the EMH is that investors do not always react in proper proportion to new information (Fischer, 2012).

Contrary to the conventional belief that the markets are rational and efficient (Fama, 1970), investors overreact to both good and bad news. Under-reaction of stock prices to news such as earnings announcements, and overreaction of stock prices to a series of good or bad news is based on investor psychological evidence and produces both underreaction and overreaction for a wide range of parameter values (Barberis, Shleifer \& Vishny, 1998). This causes unjustifiable up and down movements in the stock price and enable investors to make irrational short-term profits or losses. The prices will not reflect the true value of the stock when the market is inefficient and hence this will be followed by a correction in the prices. Persistent overweighting of recent information and underweighting of long-term fundamentals by irrational investors will result in overreaction and under-reactions of stock prices. Overreaction and under-reaction in the stock market helps to understand price formation in the stock market. The forces of demand and supply due to investor irrational behaviour has direct effect on stock price, pattern of returns and volume traded (You \& Zhang, 2011).

Investors overreact to performance of companies by selling stocks that have experienced recent losses or buying stocks that have enjoyed recent gains (Farag, 2014). Such overreaction tends to push prices beyond their fair or rational market value, only to have rational investors take the other side of the trades and bring prices back in line eventually. Contrarian investment strategies are strategies in which loser stocks are purchased and winner stocks are sold to earn superior returns. Soares and Serra (2005) explored the existence of autocorrelation in stock returns by evaluating whether there was a negative autocorrelation in the long run, and positive autocorrelation in the short run and confirmed that the phenomena was caused by investor overreactions and underreactions. 
European Journal of Accounting, Auditing and Finance Research

Vol.8, No. 7, pp.42-79, July 2020

Published by ECRTD-UK

Print ISSN: 2053-4086(Print), Online ISSN: 2053-4094(Online)

Behavioural models have been developed to explain price momentum and reversal in returns as a continuation followed by reversal in returns to reflect the dynamic interaction between news watchers and momentum traders predicted by the behavioral model (Lin, 2010). Investors are much more sensitive to reductions in financial wealth than to increases, also known as loss aversion. After prior gains, an investor becomes less loss averse because the prior gains will cushion any subsequent loss an investor might incur in future therefore making it more bearable in case it incurs loss after incurring gains. Conversely, after a prior loss, an investor becomes more loss averse: after being burned by the initial loss, investor become sensitive to additional setbacks and will avoid further investments (Barberis, Huang \& Santos, 2001).

Herding is regarded as a rational strategy for less sophisticated investors, who try to imitate the activities of successful investors since the use of their own information and knowledge lead to greater cost (Khan, Hassairi \& Viviani, 2011), thus the presence of extreme market movements could exacerbate this behavior. The cost and time of processing the amount of information generated during those periods would be higher than usual, increasing the incentives to herd. Extreme down-market movements and periods of stress have been linked to herding both directly and indirectly through market volatility to show that crises significantly increase market volatility. Mobarek, Mollah and Keasey (2014) opine that herding is more pronounced when market returns, trading volume and return volatility are high. Herd behavior is the most accepted psychological context in the creation of speculative bubbles in the financial markets because of inclination to observe winners mainly when good performance repeats itself.

An aspect of investor herd behavior is noise trading which follows the fact that investors with short time horizon are manipulating the stock prices more than long-term investors. One of the main arguments of behavioral finance is that some properties of asset prices are most probably regarded as deviations from fundamental value and caused by irrational investors called noise traders (Uygur \& Taş, 2014). Noise trader theory postulates that sentiment traders have greater impact during high-sentiment periods than during low-sentiment periods, and sentiment traders miscalculate the variance of returns undermining the mean-variance relation. Noise trading existence in the stock markets can increase price volatility and consequently the risk associated with investing in the stock market and the risk premia (De Long, 2005). The authors supported the idea that rational speculators in the presence of positive feedback investors might proceed to buy today in the hope of selling to noise traders at a higher price tomorrow, moving the prices even further away from their fundamentals. Individual investors are the culprits of stock market reactions due to noise trading (De Long, Shleifer, Summers \& Waldmann, 1990).

Myopic loss aversion explanation rests on two behavioral principles: loss aversion and mental accounting. In loss aversion, people tend to be more sensitive to decreases in their wealth than increases. This can help explain the tendency of investors to hold on to loss making stocks while selling winning stocks too early (Shefrin \& Statman, 2011). Mental accounting describes a tendency of people to place events into different mental 
European Journal of Accounting, Auditing and Finance Research

Vol.8, No. 7, pp.42-79, July 2020

Published by ECRTD-UK

Print ISSN: 2053-4086(Print), Online ISSN: 2053-4094(Online)

accounts based on superficial attributes like dividend paying stocks will be more preferred causing prices to rise.

Daniel, Hirshleifer and Subrahmanyam (1998) proposed a theory of security markets based on investor overconfidence, about the precision of private information and biased self-attribution, which causes changes in investors' confidence as a function of their investment outcomes, which leads to market underreactions and overreactions. The authors indicated that investor behaviour has been proposed as an explanation for stock market reactions such as momentum effects in the intermediate (short) horizon and return reversals in the long horizon. Irrational investors destabilize markets, by buying when prices are high and selling when they are low, whereas rational investors move the prices closer to their fundamental value, by buying when they are low and selling when they are high (Blasco, Corredor \& Ferreruela, 2012).

Mental accounting refers to the implicit method investors use to code and evaluate financial outcomes, transactions, investments, gambles etc. (Benartzi \& Thaler, 1995). Mental accounting behavior describes the propensity of people to place some events into different mental accounts based on superficial attributes. People sometimes disconnect decisions that should in principle be combined. Mental accounting is applied to explain why investors are likely to abstain from regarding his or her reference point for a stock. When a stock is purchased, a new mental account for that stock is opened. The succession score is then kept on this account indicating gains or losses relative to purchase price. A normative frame identifies that there is no substantive distinction between returns of stocks. A combination of mental accounting (Thaler, 1985) and risk seeking in the domain of losses (Kahneman \& Tversky, 1979) lead investors to hold onto losing investments and sell winners. Many private investors engage in mental accounting, meaning they make distinctions in their head that do not exist financially. Often, losses incurred are viewed separately from paper losses. This means that investors sell stocks from their portfolio too soon when they earn a profit and too late when they incur a loss. Turning a paper profit into real profits makes investors happy, but investors shy away from turning a paper loss into a real loss.

Information asymmetry drives price volatility and uninformed investors largely tend to follow the market trend, buying when prices rise and selling when they fall. Investor behavior explains excess volatility of stock prices based on short run post-earnings announcement drift (Daniel \& Hirshleifer, 2015). Many uninformed traders will simply follow any trend that they believe exists in share price behaviour and this trend chasing increases the volatility displayed by the market as these investors are unaware of the fundamental prices of the stock they are trading and so are unable to stop trading when the value is reached. Investor behavior has strong evidence to cause stock market reactions and explains the causes of market anomalies and is therefore an effective investment strategy by measuring investor irrational behaviours to determine return predictability in the financial markets. 
European Journal of Accounting, Auditing and Finance Research

Vol.8, No. 7, pp.42-79, July 2020

Published by ECRTD-UK

Print ISSN: 2053-4086(Print), Online ISSN: 2053-4094(Online)

\section{Statement of the Problem}

The decisions of investors in the stock market play an important role in determining the market trend, which then affects the economy (Wan, Cheng \& Yang, 2014). Abnormal stock returns occur when stock prices are driven away from fundamental values, then the prices gradually revert to the fundamental values. Short-term price momentum trends after earnings announcements and long-term price reversals after earnings trends explain how investor irrational behaviours drive stock prices away from the fundamental values. Investor behavior variables therefore explains stock market reactions to determine whether profit opportunities exist because of stock market reactions based on patterns of return predictability. Stock market anomalies indicate either market inefficiency i.e. profit opportunities or inadequacies in the underlying asset-pricing model. Systematic risk, size effect, liquidity (buy-ask spreads) and value effect do not hold up in different sample periods and have lost predictive power to be used as an investment strategy. Investor behavior model on stock market reactions, therefore, is an effective investment strategy to determine returns predictability in the financial markets (De Bondt \& Thaler, 1985).

Investors at the NSE equity market lost close to Kshs. 500 billion in 2016 to a market value of Kshs. 1.931 trillion as share prices declined by $25.35 \%$ compared to 2015 which was valued at Kshs. 2.42 trillion (CMA). The demand for stocks has been limited by a continued wait-and-see attitude by investors amid persistent volatility. In violation of the Bayes rules, individuals tend to overweigh recent information and under weigh prior data or base rate, hence overreaction (DeBondt \& Thaler, 1985).

Mbaluka (2008) established the existence of behavioural effects on individual investment decision making process at the NSE. Werah (2006) suggested that the behaviour of investors at the NSE is to some extent irrational regarding fundamental estimations because of anomalies such as herd behaviour, regret aversion, overconfidence and anchoring. Aduda and Muimi (2011) confirmed evidence of investor overreaction and under-reaction at the NSE. Thirikwa and Olweny (2015) found that the magnitude of the impact of the market performance on the deviation of individual stock returns was also impacted by the market capitalization and the book-to-market value was relatively low. Previous studies have looked at the impact of investor behaviour biases on investment decisions, investor performance and stock market developments. An investor behavior model is needed to explain the observed pattern of returns that explains stock returns. The research will use investor behavioral variables of herding, loss aversion, mental accounting and overconfidence to determine predictability of abnormal returns in Kenya. The research gap therefore is to determine the effect of investor behavior on stock returns in Kenya.

\section{General Objective}

The general objective is to determine the effect of investor behavior on stock returns in Kenya. 
European Journal of Accounting, Auditing and Finance Research

Vol.8, No. 7, pp.42-79, July 2020

Published by ECRTD-UK

Print ISSN: 2053-4086(Print), Online ISSN: 2053-4094(Online)

\section{Specific Objectives}

1. To determine the effect of herd behavior on stock returns in Kenya.

2. To determine the effect of loss aversion on stock returns in Kenya.

3. To determine the effect of mental accounting on stock returns in Kenya.

4. To determine the effect of overconfidence on stock returns in Kenya.

\section{Research Hypotheses}

This study will seek to address the following pertinent research hypothesis;

$\mathrm{H}_{01}$ : Herd behavior has no significant effect on stock returns in Kenya.

$\mathrm{H}_{02}$ : Loss aversion has no significant effect on stock returns in Kenya.

$\mathrm{H}_{03}$ : Mental accounting has no significant effect on stock returns in Kenya.

$\mathrm{H}_{04}$ : Overconfidence has no significant effect on stock returns in Kenya.

\section{Significance of Study}

This research will guide Capital Markets Authority on the effect of investor behavior on stock market returns in Kenya. The study will be useful to policy makers and investors in the stock markets to consider behavioural factors on their investment decisions. The study ensures economic stability can be enhanced by policy makers through putting in policies that enhance effective asset allocation in the capital markets. It will ensure the government and private planners establish ex ante rules to improve choices and efficiency, including disclosure, reporting, advertising and default-option-setting regulations. It will ensure the government should avoid actions that exacerbate investor biases because deviations in stock prices increase volatility in the stock market. CMA will use this study to monitor and regulate by ensuring listed companies to offer sufficient information promptly for the investors to reduce investor irrational behaviors.

Companies going public can use the findings of this study to understand how investor behavior influence the price of securities and hence can set realistic prices that will attract the investors they target without distorting the market. The findings of this study will help stockbrokers and fund managers to understand investor behavior and advise the investors appropriately. The Nairobi Securities Exchange and other market players can use these findings as a basis of investor education and minimization of noise trading in the Kenyan.

\section{Scope of Study}

The study determined the effect of investor behavior on stock returns in Kenya. The population for this study comprised of all the 67 listed companies at the NSE for the period of 2004 to 2016. A sample of 48 listed companies was used in this study. The period 2004 to 2016 was sufficient to cover stock returns during periods of market stress, recovery periods of the market and the current price declines experienced at the NSE. 
European Journal of Accounting, Auditing and Finance Research

Vol.8, No. 7, pp.42-79, July 2020

Published by ECRTD-UK

Print ISSN: 2053-4086(Print), Online ISSN: 2053-4094(Online)

\section{Limitation of the Study}

The process of collecting the secondary data brought challenges of companies that were listed for a short period. The study sampled companies that had been listed for at least three years prior to the date of analysis. This was to enable the research to deal with dynamics of time components and to capture investor behaviour variables and stock market reactions in Kenya. The research therefore sampled 48 of the 67 listed companies. This presented a $72 \%$ of the target population over the sample period.

\section{LITERATURE REVIEW}

Lux (1995) showed the speed of change in trading volume indicated the emergence of a bubble explained by the emergence a self-organizing process of infection among traders caused stock prices to deviate from fundamental values. Fu and Taipei (2010) found out that low turnover had high tendency to herd market return. The author indicated that turnover rate influence herding. Low turnover lacked sufficient information which led to more tendencies to herd market return. The approach of Chiang and Zheng (2010) was applied to detect market-wide herding during the period 2001-2012. Significant evidence of local market-wide herding was found in Finland during both up and down going market days. The author found evidence of local market-wide herding was found in Denmark, Norway or Sweden.

Messis and Zepranis (2014) used Hwang and Salmon (2004) to analyse investor daily, weekly and monthly data of securities traded at the Athen Stock Exchange. Thirikwa and Olweny (2015) showed evidence of herding in the NSE around market performance, market capitalization and book-to-market value. The result showed that the magnitude of the impact of the market performance on the deviation on individual stock returns, measured by $\beta_{3}$, is relatively high at 9.475 and significant at $1 \%$. Deviations in the stock returns was also impacted by the market capitalization and the Book-to-market value, though both relatively low, at $=0.670$ and $=-0.242$ at $1 \%$ significant level relatively.

Vieira and Pereira (2015) showed that herding intensity was negative and statistically significant, which concluded that investors mimicked each other in a systematic way. These different findings had an important empirical implication, since it suggested that different herding measures led to different conclusions about the existence of investor herd behavior. Lee and Lee (2015) findings confirmed that bubble and burst of prices were more likely to emerge when heterogeneous expectations about prices were combined with herding behavior among agents, so that agents in the same group shared the similar expectations about the price changes. Barberis, Huang and Santos (2001) findings indicated that the loss aversion and mental accounting framework could help explain the high mean, excess volatility and predictability of stock returns, as well as their low correlation with consumption growth. The design of the model was influenced by prospect theory and by experimental evidence on how prior outcomes affected risky choice. Barberis and Huang (2001) findings were that the typical individual stock return has a high mean and excess volatility, and there was a large value premium in the cross 
European Journal of Accounting, Auditing and Finance Research

Vol.8, No. 7, pp.42-79, July 2020

Published by ECRTD-UK

Print ISSN: 2053-4086(Print), Online ISSN: 2053-4094(Online)

section which could to some extent, be captured by a commonly used multifactor model. Bond and Satchell (2006) findings showed that when agents were loss averse, there were utility gains to be made from using models that explicitly captured this feature. These results linked the theoretical discussion on loss aversion to empirical modeling.

Jarrow and Zhao (2006) findings indicated that when asset returns were nearly normally distributed, there was little difference between the optimal M-V and M-LPM portfolios. When asset returns were not normal with large left tails, the author documented significant differences in M-V and M-LPM optimal portfolios. This observation was consistent with industry usage of $\mathrm{M}-\mathrm{V}$ theory for equity portfolios but not for fixedincome portfolios. Gächter, Johnson and Herrmann (2007) found that substantial heterogeneity in both measures of loss aversion. Loss aversion in the riskless choice task and loss aversion in the risky choice task were highly significantly and strongly positively correlated. The research found that in both choice tasks loss aversion increases in age, income, and wealth, and decreases in education.

Brenner, Rottenstreich, Sood and Bilgin (2007) experimental results showed endowment effect reversals consistent with Possession Loss Aversion. Harinck, Beest, Dijk and Zeeland (2012) consistently showed that using within - and between - subject designs and anticipated and real coin-toss gambles the strength of loss aversion depended on the measurement format i.e. fill-in-the-loss versus fill-in-the-gain; filling in the loss side increased loss aversion. Easley and Yang (2015) showed that if loss aversion was the only difference in investors' preferences, then for empirically relevant parameter values, loss-averse investors was driven out of the market and did not affect long run prices. The selection process was slow in terms of wealth shares; but it was effective in terms of price impacts, because of endogenous withdrawal by loss-averse investors from the stock market. Overall, the market selection mechanism was efficient.

Keim (1985) findings showed that much of the phenomenon was due to a nonlinear relation between dividend yields and returns in January. Regression coefficients on dividend yields, which some models predicted should be non-zero due to differential taxation of dividends and capital gains, exhibited a significant January seasonal, even when controlling for size. This finding was significant since there were no provisions in the after-tax asset pricing models that predict the tax differential was more important in January than in other months. Thaler and Johnson (1990) findings considered how prior outcomes were combined with the potential payoffs offered by current choices and proposed an editing rule to describe how decision makers framed such problems. The authors also presented data from real money experiments supporting a house money effect increased risk seeking in the presence of a prior gain and break-even effects in the presence of prior losses, outcomes which offered chances to break even were especially attractive. 
European Journal of Accounting, Auditing and Finance Research

Vol.8, No. 7, pp.42-79, July 2020

Published by ECRTD-UK

Print ISSN: 2053-4086(Print), Online ISSN: 2053-4094(Online)

Heath, Chatterjee and France (1995) findings demonstrated that mental accounting principles, price perception and reference dependence were sensitive to the ways in which deviations from reference states were framed. Barberis and Huang (2001) findings were that the typical individual stock return had a high mean and excess volatility, and there was a large value premium in the cross section which could, to some extent, be captured by a commonly used multifactor model. Lim (2004) result was consistent with the principles of mental accounting (Thaler, 1985), according to which individuals attained higher utility by integrating losses and segregating gains. Lim (2006) found that the degree of trade clustering was related to investors' stock preferences and portfolio returns.

Kumar and Lim (2008) found that the degree of trade clustering was related to investors' stock preferences and portfolio returns. Collectively, the evidence indicated that the choice of decision frames was likely to be an important determinant of investment decisions. Park (2010) results demonstrated that the dividend-price ratio generally had a predictive power for stock returns when both are $\mathbf{I}(0)$. However, the results also showed that the dividend-price ratio lost its predictive power when it became I (1) and were robust across countries. Frydman, Hartzmark and Solomon (2015) findings indicated that when trading the new position, investors exhibited a disposition effect based on the amount invested in the original position that was no longer in the portfolio. Daniel, Hirshleifer and Subrahmanyam (1998) explained that overconfidence implied negative long-lag autocorrelations, excess volatility, and, when managerial actions were correlated with stock mispricing, public-event-based return predictability. Daniel and Titman (1999) analysis suggested that investor overconfidence generated momentum in stock returns and that that momentum effect was likely to be strongest in those stocks whose valuations required the interpretation of ambiguous information.

Barber and Odean (2001) documented that men trade 45 percent more than women. Trading reduced men's net returns by 2.65 percentage points a year as opposed to 1.72 percentage points for women. Daniel, Hirshleifer and Subrahmanyam (2001) indicated that with many securities, mispricing of idiosyncratic value components diminished but systematic mispricing did not. The theory offered untested empirical implications about, and was consistent with several empirical findings. These included the ability of fundamental/price ratios and market value to forecast returns, and the domination of beta by those variables in some studies. Scott, Stumpp and Xu (2003) found consistent investor overconfidence behavior across different countries and trading environments.

Biais, Hilton, Mazurier and Pouget (2005) empirical results showed that miscalibration reduced and self-monitoring enhanced trading performance. The effect of the psychological variables was strong for men but non-existent for women. Statman, Thorley and Vorkink (2006) found that share turnover was positively related to lag returns for many months. The relationship held for both market-wide and individual security turnover, which was interpreted as evidence of investor overconfidence and the 
European Journal of Accounting, Auditing and Finance Research

Vol.8, No. 7, pp.42-79, July 2020

Published by ECRTD-UK

Print ISSN: 2053-4086(Print), Online ISSN: 2053-4094(Online)

disposition effect, respectively. Security volume was more responsive to market return shocks than to security return shocks, and both relationships were more pronounced in small-cap stocks and in earlier periods where individual investors held a greater proportion of share. Ko and Huang (2007) findings indicated that overconfidence generally improved market pricing provided the level of overconfidence was not too high. Glaser and Weber (2007) found that investors who thought that they were above average in terms of investment skills or past performance but who did not have above average performance in the past traded more. Measures of miscalibration were, contrary to theory, unrelated to measures of trading volume. This result was striking as theoretical models that incorporated overconfident investors mainly motivated this assumption by the calibration literature and modeled overconfidence as underestimation of the variance of signals. About other recent findings, the author concluded that the usual way of motivating and modeling overconfidence which was mainly based on the calibration literature must be treated with caution. Moreover, the authors' way of empirically evaluating behavioral finance models, the correlation of economic and psychological variables and the combination of psychometric measures of judgment biases, such as overconfidence scores, and field data seemed to be a promising way to better understand which psychological phenomena drove economic behavior.

Zaiane and Abaoub (2009) based on the work of Statman, Thorley and Vorkink (2006) and by using VAR models and impulse response functions, the results indicated a little evidence of the overconfidence hypothesis when volume i.e. shares traded was used as proxy of trading volume. Huisman, Sar and Zwinkels (2010) results indicated that the expected volatilities resulting from the Pearson-Tukey measure were even lower than those from the Parkinson (1980) measure. Results confirmed that surveyed retail investors exhibited a significant overconfidence bias. Yeoh and Wood (2011) findings were that overconfident participants undertook smaller but more frequent trades. Durand, Newby, Tant and Trepongkaruna (2013) findings indicated that personality traits were associated with overconfidence and overreaction in financial markets.

Adel and Mariem (2013) results achieved through the application of tests and VAR modeling ARMA-EGARCH indicated the importance of confidence bias in the analysis of characteristics of the Tunisian financial market. Jlassi, Naoui and Mansour (2013) findings indicated that overconfidence was more pronounced for the advanced markets relatively to the emerging ones. With the exception of some Asian and Latin American markets overconfidence was presented in both up and down markets. Evidence suggested that overconfidence was the main incentive that triggered and prolonged the global financial crisis in the US market and in other continents. Finding showed that overconfidence still existed even during the recession period, but at different levels.

Boussaidi (2013) results indicated that the overconfidence hypothesis was confirmed only for one third of the firms composing the sample. The sum of the lagged coefficients associated to turnover was positive and significant. Tariq and Ullah (2013) results 
European Journal of Accounting, Auditing and Finance Research

Vol.8, No. 7, pp.42-79, July 2020

Published by ECRTD-UK

Print ISSN: 2053-4086(Print), Online ISSN: 2053-4094(Online)

indicated that return volatility had significant impact on returns but it hadn't gotten any significant impact on turnover and previous days' returns had significant positive impact on today's turnover. Metwally and Darwish (2015) results indicated that the influence of past market return to the market turnover in volume only existed in the first lag, since the second lag of market return was not significant. The positive impact of the lagged market returns on the market turnover fitted the overconfidence hypothesis, although the effect was not as strong as expected. The results were presented using the five lags selection criteria of the VAR model. It was found that Schwartz Criteria was supporting the result at lag 2, while the other four criteria were all significant at lag.

DeBondt and Thaler (1985) findings indicated that based on CRSP monthly return data; there was consistency with overreaction hypothesis that shed new light on the January returns earned by prior winners and losers. Jegadeesh and Titman (1993) found that the profitability of these strategies are not due to their systematic risk or to delayed stock price reactions to common factors. However, part of the abnormal returns generated in the first year after portfolio formation dissipated in the following two years. A similar pattern of returns around the earnings announcements of past winners and losers was also documented.

\section{RESEARCH METHODOLOGY}

\section{Data Processing and Analysis}

The panel data regression model adopted is the Auto Regressive Distributed Lag model because of panels in which both $\mathrm{T}$, the number of time series observations, and $\mathrm{N}$, the number of groups are quite large and of the same order of magnitude. Mean Group estimators estimate $\mathrm{N}$ separate regressions and calculate the coefficient means or to pool the data and assume that the slope of coefficients and error variances are identical. Pooled Mean Group estimator constraints the long run coefficients to be identical but allows short run coefficients and error variances to differ across groups. Pool Mean Group estimator considers both cases where the independent variables are stationary or where they follow unit root process, and for both cases derive the asymptotic distribution of the Pool Mean Group estimator as T tends to infinity.

\section{Measurement of Study Variables}

Herding behavior, loss aversion behaviour, mental accounting behaviour and overconfidence behaviour are the independent variables. Stock returns is the dependent variable.

\section{Stock Returns}

Stock returns was measured using abnormal returns. Excess return $\mathrm{AR}_{\mathrm{it}}$ are computed as the difference between the stock return and the market portfolio return to get market adjusted return. Market adjusted returns was measured as follows:

Abnormal return $=$ Observed return - Expected return 
European Journal of Accounting, Auditing and Finance Research

Vol.8, No. 7, pp.42-79, July 2020

Published by ECRTD-UK

Print ISSN: 2053-4086(Print), Online ISSN: 2053-4094(Online)

$$
A R_{i, t}=R_{i, t}-R_{m, t}
$$

Where for the monthly period $t$, market return constant $R_{m t}$ is subtracted from $R_{i t} R_{m t}$ is the equal-weighted return of the entire 20 share index. There is no risk adjustment except for movements of the market as a whole and the adjustment is identical for all stocks (De Bondt \& Thaler, 1985); (Boussaidi, 2017).

\section{Herd Behaviour}

Investor herd behavior was measured using return dispersions using Cross Sectional Absolute Deviations (CSAD) method (Thirika \& Olweny, 2015). CSAD is expressed as

$$
C S A D_{i t}=\left|r_{i t}-r_{m t}\right|
$$

CSAD is the measure of dispersion, where $\mathrm{N}$ is the number of firms in the aggregate market portfolio, $r_{i t}$ is the observed stock return on firm $i$ for month $t$, and $r_{m t}$ is the cross-sectional average return on month $t$. This means that the dispersions will decrease or at least increase at a less-than-proportional rate with the market return. Herding exists when there is a small difference between the returns of individual stock and the market index.

\section{Loss Aversion}

Loss aversion behaviour is measured using utility of gains or losses of prior returns to measure loss aversion behavior (Barberis \& Huang, 2001). The gain or loss on stock $i$ between time $t$ and $t+1$ was measured as follows:

$$
X_{i, t+1}=S_{i, t} R_{i, t+1}-S_{i, t} R_{f, t}
$$

Where $X i, t \_1$ measures the gain or loss on stock $i$ between time $t$ and time $t \_1$, a positive value indicating a gain and a negative value, a loss. The utility the investor receives from this gain or loss is given by the function $\mathrm{v}$, and it is added up across all stocks owned by the investor. It is a function not only of the gain or loss itself, but also of $S i, t$, the value of the investor's holdings of stock $i$ at time $t$, and of a state variable $z i$, $t$, which measures the investor's gains or losses on the stock prior to time $t$ as a fraction of $S i, t$. By including $S i, t$ and $z i, t$ as arguments of v, we allow the investor's prior investment performance to affect the way subsequent losses are experienced. In words, the gain is the value of stock $i$ at time $t+1$ minus its value at time $t$ multiplied by the risk-free rate. Expected return lead by one month minus equals to market return minus risk free rate.

\section{Mental Accounting}

Investor Mental Accounting is measured using Price-dividend ratio. Price-dividend ratio is financial ratio that indicates how much a company pays out in dividends each year relative to its share price. A stock with a high price-dividend ratio (a growth stock) is often one that has done well in the past, accumulating prior gains for the investor, who 
European Journal of Accounting, Auditing and Finance Research

Vol.8, No. 7, pp.42-79, July 2020

Published by ECRTD-UK

Print ISSN: 2053-4086(Print), Online ISSN: 2053-4094(Online)

then views it as less risky and requires a lower average return. A stock with a low pricedividend ratio (a value stock) has often had dismal prior performance, burning the investor, who now views it as riskier, and requires a higher average return.

The investor mental accounting variable was first calculated by forming five portfolios. The portfolios formation was based on the price-divided ratio annually. These portfolios were rebalanced each year to form new portfolios. Barberis and Huang (2001) subtracted the average returns of the portfolio of the companies that had the highest price-divided ratio from the average returns of the companies that had the lowest price-divided ratio. This resulted in a portfolio referred to as difference portfolio. The intention of creating this portfolio is to assess whether mental accounts formed on the basis of the pricedivided ratio have any explanatory power on the market reaction. It is to assess whether the companies that pay lower divided are able to beat the high paying divided companies.

Stocks with low price-dividend ratios (dividend yield) have higher average returns than stocks with high price-dividend ratios. Multifactor models that have been shown to use the value premium in actual data and matches empirical features of aggregate asset return (Barberis \& Huang, 2001). In equilibrium, aggregate stock returns have a high mean, excess volatility, and are moderately predictable in the time series, while the riskfree rate is constant and low.

\section{Investor Overconfidence}

Investor overconfidence shall be measured using trading volume to ascertain turnover. Turnover rate will be used as a measure of volume of transactions (Adel \& Mariem, 2013). The trading volume is measured by turnover as follows:

turnover $=\frac{\text { nit }}{\text { Nit }}$

Where nit is the number of shares traded of stock $\mathrm{i}$ (volume traded per month); Nit is the number of exchanges of stock $\mathrm{i}$ (number of deals); $\mathrm{t}$ is time; $\mathrm{i}$ is listed company. Excessive trading of shares on investor confidence contributes to excessive volatility (Adel \& Mariem, 2013). 
European Journal of Accounting, Auditing and Finance Research

Vol.8, No. 7, pp.42-79, July 2020

Published by ECRTD-UK

Print ISSN: 2053-4086(Print), Online ISSN: 2053-4094(Online)

Table 3.1 Summary of Measuring Variables

\begin{tabular}{|c|c|c|c|c|}
\hline $\begin{array}{l}\text { Dependent } \\
\text { variable }\end{array}$ & $\begin{array}{l}\text { Measurable } \\
\text { Variable }\end{array}$ & $\begin{array}{l}\text { Method of } \\
\text { variable } \\
\text { measure }\end{array}$ & $\begin{array}{l}\text { Empirical } \\
\text { Review }\end{array}$ & Data \\
\hline Stock Returns & $\begin{array}{l}\text { (Abnormal } \\
\text { Returns) }\end{array}$ & $A R_{i, t}=R_{i, t}-R_{m, t}$ & $\begin{array}{l}\text { De Bondt and } \\
\text { Thaler } \\
(1985)\end{array}$ & Past returns \\
\hline $\begin{array}{l}\text { Independent } \\
\text { Variables }\end{array}$ & $\begin{array}{l}\text { Measurable } \\
\text { Variable }\end{array}$ & $\begin{array}{l}\text { Method of } \\
\text { variable } \\
\text { measure }\end{array}$ & $\begin{array}{l}\text { Empirical } \\
\text { Review }\end{array}$ & Data \\
\hline $\begin{array}{l}\text { Investor Herd } \\
\text { Behaviour }\end{array}$ & $\begin{array}{l}\text { Return } \\
\text { dispersion }\end{array}$ & CSAD & $\begin{array}{l}\text { Thirika and } \\
\text { Olweny } \\
(2015)\end{array}$ & Past returns \\
\hline $\begin{array}{l}\text { Investor Loss } \\
\text { Aversion }\end{array}$ & $\begin{array}{l}\text { Utility of } \\
\text { gains/ losses }\end{array}$ & $\begin{array}{l}\text { Prior gains } \\
\text { and losses }\end{array}$ & $\begin{array}{l}\text { Barberis and } \\
\text { Huang (2001) }\end{array}$ & Past returns \\
\hline $\begin{array}{l}\text { Investor Mental } \\
\text { Accounting }\end{array}$ & $\begin{array}{l}\text { Price- } \\
\text { dividend } \\
\text { ratio }\end{array}$ & $\begin{array}{l}\text { Value } \\
\text { premium }\end{array}$ & $\begin{array}{l}\text { Barberis and } \\
\text { Huang (2001) }\end{array}$ & Past returns \\
\hline $\begin{array}{l}\text { Investor } \\
\text { Overconfidence }\end{array}$ & $\begin{array}{l}\text { Trading } \\
\text { volume }\end{array}$ & $\begin{array}{l}\text { Turnover } \\
\text { rate }\end{array}$ & $\begin{array}{l}\text { Adel and } \\
\text { Mariem } \\
(2013)\end{array}$ & $\begin{array}{l}\text { Trading volume and } \\
\text { number of deals }\end{array}$ \\
\hline
\end{tabular}

Note: CSAD is Cross Section Absolute Deviation

\section{Statistical Model}

Panel data regression models was used to pool data observations on a cross-section of the sampled 48 listed companies under study over a period of thirteen years. The study used panel regression models to analyze secondary data as the secondary data collected will exhibit both time series and cross-sectional dimensions. Stock market reactions variable was modelled because of herding, loss aversion, mental accounting and overconfidence. The study determined the effect investor behavior on stock returns in Kenya, panel regression equation will be specified as follows:

$S M R_{i t}=\alpha_{i t}+\beta_{1} X_{1 i t}+\beta_{2} X_{2 i t}+\beta_{3} X_{3 i t}+\beta_{4} X_{4 i t}+\mu_{i t}$

: $\mathrm{SMR}_{\text {it }}$ is Stock Market Returns as measured by Abnormal Returns to determine stock market reaction, $\mathrm{X}$ is the investor behaviour variables (Investor Herd Behaviour, Investor Loss Aversion, Investor Mental Accounting and Investor Overconfidence). The variable effect on the stock market to determine if there is overreaction or underreaction in the stock market. $\alpha_{0}$ is the intercept term, $\alpha_{i}$ are the independent variables, $\mu_{i t}$ is the error term (the time-varying disturbance term is serially uncorrelated with mean zero 
European Journal of Accounting, Auditing and Finance Research

Vol.8, No. 7, pp.42-79, July 2020

Published by ECRTD-UK

Print ISSN: 2053-4086(Print), Online ISSN: 2053-4094(Online)

and constant variance). $i=1 \ldots 67$ companies listed at the NSE, $t=$ time in years from 2004 to 2016 to determine the effects of investor behavior on stock market reactions.

\section{RESULTS}

Descriptive Statistics for Dependent and Independent Variables Table 4.1 Descriptive Statistics

\begin{tabular}{lccccc}
\hline & $\begin{array}{c}\text { Stock } \\
\text { Returns }\end{array}$ & $\begin{array}{c}\text { Investor } \\
\text { Herd } \\
\text { Behavior }\end{array}$ & $\begin{array}{c}\text { Investor } \\
\text { Loss } \\
\text { Aversion }\end{array}$ & $\begin{array}{c}\text { Investor } \\
\text { Mental } \\
\text { Accounting }\end{array}$ & $\begin{array}{c}\text { Investor } \\
\text { Overconfid } \\
\text { ence }\end{array}$ \\
Mean & 0.239585 & 7.446169 & -2.120756 & 1.271245 & 7.452941 \\
Median & -0.325554 & 4.978227 & 0.109167 & 0.515701 & 7.599967 \\
Maximum & 122.4242 & 122.4242 & 958.8919 & 53.17610 & 14.38127 \\
Minimum & -97.94357 & 0.002961 & -1199.735 & -31.50250 & -0.572519 \\
Std. Dev. & 12.10587 & 9.547525 & 107.5521 & 8.298008 & 1.825437 \\
Skewness & 0.512158 & 4.451179 & -0.791119 & 1.762223 & -0.355976 \\
Kurtosis & 19.61086 & 32.89297 & 18.30443 & 14.78702 & 4.150125 \\
& & & & & \\
Jarque-Bera & 73258.50 & 257316.5 & 62141.37 & 40033.52 & 483.9462 \\
Probability & 0.000000 & 0.000000 & 0.000000 & 0.000000 & 0.000000 \\
& & & & & \\
Sum & 1520.883 & 47268.28 & -13360.76 & 8069.866 & 47311.27 \\
Sum Sq. & 930165.6 & 578562.3 & 72863450 & 437035.0 & 21149.60 \\
Dev. & & & & & \\
\hline
\end{tabular}

Table 4.1 presents some elementary tests of descriptive statistics and normality. From the results, the standard deviation of the variables was found to be outside the acceptable range of 3 standard deviations for stock market returns, investor herd behavior, investor loss aversion, investor mental accounting variables while investor overconfidence was within the normal distribution bound. The results of standard deviation were supported by those of skewness which is a measure of dispersion with only investor overconfidence having skewness close to zero.

The skewness value for all the other variables shows that the variables are not all normally distributed since their value of skewness disperses from zero significantly. In extension, the result of kurtosis was away from the expected value of 4 for a normal distribution for stock returns, investor herd behavior, investor loss aversion, investor mental accounting variables and only investor overconfidence had a value of 4 . The probabilities of the Jarque-bera are all away from the value of one (1) which means that all the variables are not normally distributed per this test statistic which weighs the information between skewness and kurtosis. The interpretation is that special methods that takes care of the dispersions from normality was adopted to minimize any bias that may arise. 
European Journal of Accounting, Auditing and Finance Research

Vol.8, No. 7, pp.42-79, July 2020

Published by ECRTD-UK

Print ISSN: 2053-4086(Print), Online ISSN: 2053-4094(Online)

The results for descriptive statistics for stock returns showed that for mean is 0.239585 , median is 0.325554 , maximum is 122.4242 , minimum is -97.94357 , standard deviation is 12.10587, skewness is 0.512158, kurtosis is 19.61086 and Jarque-Bera is 73258.50 . The probability is 0 meaning the data is not normally distributed. When data is normally distributed the $\mathrm{p}$-value is 1 .

The results for descriptive statistics for Investor Herd Behavior showed that for mean is 7.446169 , median is 4.978227 , maximum is 122.4242 , minimum is 0.002961 , standard deviation is 9.547525 , skewness is 4.451179 , kurtosis is 32.89297 and Jarque-Bera is 257316.5. The probability is 0 meaning the data is not normally distributed. When data is normally distributed the p-value is 1 .

The results for descriptive statistics for Investor Loss Aversion showed that for mean is 2.120756, median is 0.109167 , maximum is 958.8919 , minimum is -1199.735 , standard deviation is 107.5521, skewness is -0.791119 , kurtosis is 18.30443 and Jarque-Bera is 62141.37. The probability is 0 meaning the data is not normally distributed. When data is normally distributed the p-value is 1 .

The results for descriptive statistics for Investor Mental Accounting showed that for mean is -1.271245 , median is 0.515701 , maximum is 53.17610 , minimum is -31.50250 , standard deviation is 8.29808 , skewness is 1.762223 , kurtosis is 14.78702 and JarqueBera is 40033.52. The probability is 0 meaning the data is not normally distributed. When data is normally distributed the p-value is 1 .

The results for descriptive statistics for Investor Overconfidence showed that for mean is 7.452941 , median is 7.599967 , maximum is 14.38127 , minimum is -0.572519 , standard deviation is 1.825437 , skewness is 0.355976 , kurtosis is 4.150125 and Jarque-Bera is 483.9462. The probability is 0 meaning the data is not normally distributed. When data is normally distributed, the $\mathrm{p}$ value is 1 .

\section{Model Specification Tests \\ Unit Root Test \\ Stock Returns Unit Root Test \\ Table 4.2 Stock Market Reaction Unit Root Test}

\begin{tabular}{|c|c|c|c|c|}
\hline \multicolumn{5}{|l|}{$\begin{array}{l}\text { Panel unit root test: Summary } \\
\text { Series: Stock Returns }\end{array}$} \\
\hline Method & Statistic & P-value & $\begin{array}{l}\text { Cross- } \\
\text { sections }\end{array}$ & Observation \\
\hline \multicolumn{5}{|c|}{ Null: Unit root (assumes common unit root process) } \\
\hline Levin, Lin \& Chu t* & -96.0960 & 0.0000 & 48 & 6292 \\
\hline \multicolumn{5}{|c|}{ Null: Unit root (assumes individual unit root process) } \\
\hline Im, Pesaran and Shin W-stat & -87.1475 & 0.0000 & 48 & 6292 \\
\hline ADF - Fisher Chi-square & 3582.55 & 0.0000 & 48 & 6292 \\
\hline PP - Fisher Chi-square & 3697.44 & 0.0000 & 48 & 6300 \\
\hline
\end{tabular}


European Journal of Accounting, Auditing and Finance Research

Vol.8, No. 7, pp.42-79, July 2020

Published by ECRTD-UK

Print ISSN: 2053-4086(Print), Online ISSN: 2053-4094(Online)

Panel Unit Root Test: Summary

Series: Investor Herd Behavior

$\begin{array}{lrcrr}\text { Method } & \begin{array}{r}\text { Statistic } \\ \text { Null: Unit root (assumes common unit root process) }\end{array} & \text { P-value } & \begin{array}{c}\text { Cross- } \\ \text { sections }\end{array} & \text { Observation } \\ \text { Levin, Lin \& Chut* } & -67.8411 & 0.0000 & 48 & 6295 \\ & & & & \\ \text { Null: Unit root (assumes individual unit root process) } & & & \\ \text { Im, Pesaran and Shin W-stat } & -62.9233 & 0.0000 & 48 & 6295 \\ \text { ADF - Fisher Chi-square } & 2729.07 & 0.0000 & 48 & 6295 \\ \text { PP - Fisher Chi-square } & 2874.81 & 0.0000 & 48 & 6300\end{array}$

Panel unit root test: Summary

Series: Investor Loss Aversion

$\begin{array}{ll}\text { Method } & \text { Statistic } \\ \text { Null: Unit root (assumes common unit root process) }\end{array}$

Null: Unit root (assumes common unit root process)
Levin, Lin \& Chut*

P-value

Cross-

Null: Unit root (assumes individual unit root process)

Im, Pesaran and Shin W-stat $\quad-86.6497$

ADF - Fisher Chi-square $\quad 3511.31$

PP - Fisher Chi-square

3807.87

0.0000

0.0000

0.0000

sections

Observation

0.0000

48

6236

Panel unit root test: Summary

Series: Investor Mental Accounting

Method Statistic
Null: Unit root (assumes common unit root process)

P-value

Cross-

Null: Unit root (assumes common unit root process)
Levin, Lin \& Chu t*

0.0000

sections

Observation

$-91.3319$

Null: Unit root (assumes individual unit root process)

Im, Pesaran and Shin W-stat

$-83.5193$

ADF - Fisher Chi-square

3642.26

PP - Fisher Chi-square

3642.29

0.0000

0.0000

0.0000

48

6300

Panel Unit Root Test: Summary

Series: Investor Overconfidence

Method Statistic
Null: Unit root (assumes common unit root process)

Levin, Lin \& Chu t*

$-9.00532$

P-value

Cross-

Null: Unit root (assumes individual unit root process)

Im, Pesaran and Shin W-stat

$-15.5181$

ADF - Fisher Chi-square

499.442

PP - Fisher Chi-square

1075.90

0.0000

48

48

6300

6300

48

6300

6236

6252

PP - Fisher Chi-square

0.0000

0.0000

0.0000

sections

Observation

48

6250 
European Journal of Accounting, Auditing and Finance Research

Vol.8, No. 7, pp.42-79, July 2020

Published by ECRTD-UK

Print ISSN: 2053-4086(Print), Online ISSN: 2053-4094(Online)

The results from the unit root test for all the cross-sections in the variable stock market reaction in table 4.2 above shows that all the 48 cross sections in the were stationary. The first part of the table presents the common unit root test developed by Levin, Lin and Chu (2002). The test shows that considered simultaneously all the cross-section are stationary for the stock market reaction variable. In other words, they do not have the unit root problem since the null hypothesis of unit root is rejected as depicted by the significant p-value of 0.0000 .

The lower section presents three test of stationarity in panel data setting. These are Im, Pesaran and Shin (2003), ADF - Fisher Chi-square Maddala, and Wu (1999), PP - Fisher Chi-square (Choi, (2001). These tests assume the test of unit root on individual cross sections. As depicted by the p-values which are very statistically significant, the null hypothesis of non-stationarity was rejected. The interpretation was that the stock market reaction variable was stationary in the two cases of test. In conclusion, the test of stationarity is important because it help to identify the order of integration of a variable and avoid spurious regression. In this case the stock returns variable is integrated of order zero $(0)$.

The results from the unit root test for all the cross-section in table 4.3 above shows that all the 48 cross sections in the investor herd behavior variable were stationary. The first part of the table presents the common unit root test developed by Levin, Lin and Chu (2002). The test shows that considering simultaneously all the cross-section are all stationary for the investor herd behavior variable. In other words, they do not have the unit root problem since the null hypothesis of unit root is rejected as depicted by the significant $\mathrm{p}$-value of 0.0000 .

The lower section presents three test of stationary in panel data setting. These are Im, Pesaran and Shin (2003), ADF - Fisher Chi-square, Maddala, and Wu (1999), PP Fisher Chi-square (Choi, 2001). These tests assume the test of unit root on individual cross-sections. As depicted by the p-values which are very statistically significant, the null hypothesis of non-stationarity was rejected. The interpretation was that the investor herd behavior variable was stationary in the two cases of test. In conclusion, the test of stationarity is important because it helps identify the order of integration of a variable and avoid spurious regression. In this case, the investor herd behavior variable is integrated of order zero (0).

The results from the unit root test for all the cross-sections in table 4.4 above shows that all the 48 cross-sections for the investor loss aversion variable were stationary. The first part of the table presents the common unit root test developed by Levin, Lin and Chu (2002). The test shows that considering simultaneously the cross section are all stationary for the investor loss aversion variable. In other words, they do not have the unit root problem since the null hypothesis of unit root is rejected as depicted by the significant p-value of 0.0000 . 
European Journal of Accounting, Auditing and Finance Research

Vol.8, No. 7, pp.42-79, July 2020

Published by ECRTD-UK

Print ISSN: 2053-4086(Print), Online ISSN: 2053-4094(Online)

The lower section presents three other tests of stationarity in panel data setting. These are Im, Pesaran and Shin (2003), ADF - Fisher Chi-square Maddala, and Wu (1999), PP - Fisher Chi-square (Choi, (2001). These tests assume the test for unit root on individual cross sections. As depicted by the p-values which are very statistically significant, the null hypothesis of non-stationarity was rejected. The interpretation was that the investor loss aversion variable was stationary in the two cases of test. In conclusion, the test of stationarity is important because it helps to identify the order of integration of a variable and avoid spurious regression. In this case, the investor loss aversion variable is integrated of order zero (0).

The results from the unit root test for all the cross-sections in table 4.5 above shows that all the 48 cross sections for the investor mental accounting variable are stationary. The first part of the table presents the common unit root test developed by Levin, Lin and Chu (2002). The test shows that considered simultaneously in the cross-section are all stationary for the investor mental accounting variable. In other words, they do not have the unit root problem since the null hypothesis of unit root is rejection as depicted by the significant $\mathrm{p}$-value of 0.0000 .

The lower section presents yet another three test of stationarity in panel data setting. These are Im, Pesaran and Shin (2003), ADF - Fisher Chi-square Maddala, and Wu (1999), PP - Fisher Chi-square (Choi, (2001). These tests assume the test of unit root on individual cross sections. As depicted by the p-values which are very statistically significant, the null hypothesis of non-stationarity was rejected. The interpretation was that the investor mental accounting variable was stationary in the two cases of test. In conclusion, the test of stationarity is important because it helps identify the order of integration of a variable and avoid spurious regression. In this case the investor mental accounting variable is integrated of order zero (0).

The results from the unit root test for all the variables in table 4.6 above shows that all the 48 cross sections of the investor overconfidence variable were stationary. The first part of the table presents the common unit root test developed by Levin, Lin and Chu (2002). The test shows that considered simultaneously all the cross section are all stationary for the investor overconfidence variable. In other words, they do not have the unit root problem since the null hypothesis of unit root is rejection as depicted by the significant p-value of 0.0000 .

The lower section presents yet another three test of stationarity in panel data setting. These are Im, Pesaran and Shin (2003), ADF - Fisher Chi-square Maddala, and Wu (1999), PP - Fisher Chi-square (Choi, (2001). These tests assume the test of unit root on individual cross sections. As depicted by the p-values which are very statistically significant, the null hypothesis of non-stationarity was rejected. The interpretation is that the Investor overconfidence variable is stationary in the two cases of test. In conclusion, the test of stationarity is important because it helps to identify the order of integration of a variable and avoid spurious regression. In this case, the investor overconfidence variable is integrated of order zero (0). 
European Journal of Accounting, Auditing and Finance Research

Vol.8, No. 7, pp.42-79, July 2020

Published by ECRTD-UK

Print ISSN: 2053-4086(Print), Online ISSN: 2053-4094(Online)

\section{Cross-Sectional Dependence Test (CSDT)}

In estimating panel models, it is normally assumed that the cross-sections used are independent especially when the number of observations $(\mathrm{N})$ is large. Findings by various researchers have found that cross-sectional dependence in estimation is frequently present in panel setting. Failing to take care of cross-sectional dependence in the estimation process can have serious consequence. This is the case because the unaccounted for residual dependence results in estimator inefficiency and invalid test results.

\section{Herd Behaviour}

Table 4.7 Investor Herd Behavior (CSDT)

Null hypothesis: No Cross-Section Dependence (Correlation)

Series: Investor Herd Behavior

Test

Breusch-Pagan LM

Pesaran scaled LM

Bias-corrected scaled LM

Pesaran CD
Statistic

1812.800

13.40706

13.25222

16.10668
Degrees of

freedom

1128

0.0000

0.0000

0.0000

0.0000

Null hypothesis: No Cross-Section Dependence (Correlation)

Test

Breusch-Pagan LM

Pesaran scaled LM

Bias-corrected scaled LM

Pesaran CD
Statistic

5607.528

93.30050

93.14465

53.15335
Degrees of freedom.

Null hypothesis: No Cross-Section Dependence (Correlation)

Series: Investor Loss Aversion
Statistic

127767.1

2665.223

2665.068

350.3421
1128

0.0000

0.0000

0.0000

0.0000
Breusch-Pagan LM

Pesaran scaled LM

Bias-corrected scaled LM

Pesaran CD
Degrees of freedom

1128

0.0000

0.0000

0.0000

0.0000

Null hypothesis: No Cross-section Dependence (Correlation)

Series: Investor Mental Accounting 
European Journal of Accounting, Auditing and Finance Research

Vol.8, No. 7, pp.42-79, July 2020

Published by ECRTD-UK

Print ISSN: 2053-4086(Print), Online ISSN: 2053-4094(Online)

Test

Breusch-Pagan LM

Pesaran scaled LM

Bias-corrected scaled LM

Pesaran CD
Statistic

46266.44

949.3251

949.1703

203.4395
Degrees of freedom

Null hypothesis: No cross-section dependence (correlation)

\section{Series: Investor Overconfidence}

Test

Breusch-Pagan LM

Pesaran scaled LM

Bias-corrected scaled LM

Pesaran CD
Statistic

2113.472

19.73735

19.58251

16.34837
Prob.

1128

0.0000

0.0000

0.0000

0.0000

\begin{tabular}{lccc}
\multicolumn{1}{c}{ Test } & Statistic & $\begin{array}{c}\text { Degrees of } \\
\text { freedom }\end{array}$ & Prob. \\
Breusch-Pagan LM & 2113.472 & 1128 & 0.0000 \\
Pesaran scaled LM & 19.73735 & & 0.0000 \\
Bias-corrected scaled LM & 19.58251 & & 0.0000 \\
Pesaran CD & 16.34837 & & 0.0000
\end{tabular}

Table 4.7 above presents the results on cross-sectional independence of individuals in a panel series. The null hypothesis of no cross-sectional dependence (correlation) is tested against that of cross-sectional dependence. From the test statistics employed BreuschPagan LM, Pesaran scaled LM, Bias-corrected scaled LM and Pesaran CD it was evident that there is cross-sectional dependence in this variable. The p-value gives a strong evidence against the null hypothesis. The interpretation is that some information in each of the cross-sections has the tendency to flow it other cross-sections.

Table 4.8 above presents the results on cross-sectional independence of individuals in a panel series. The null hypothesis of no cross-sectional dependence (correlation) is tested against that of cross-sectional dependence. From the test statistics employed, BreuschPagan LM, Pesaran scaled LM, Bias-corrected scaled LM and Pesaran CD it was evident that there is cross-sectional dependence in this variable. The p-value gives a strong evidence against the null hypothesis. The interpretation is that some information in each of the cross-sections has the tendency to flow it other cross-sections.

Table 4.9 above presents the results on cross-sectional dependence of individuals in a panel series. The null hypothesis of no cross-sectional dependence (correlation) is tested against that of cross-sectional dependence. From the test statistics employed, BreuschPagan LM, Pesaran scaled LM, Bias-corrected scaled LM and Pesaran CD, it is evident that there is cross-sectional dependence in this variable. The p-value gives a strong evidence against the null hypothesis. The interpretation is that some information in each of the cross-sections has the tendency to flow to other cross-sections. 
European Journal of Accounting, Auditing and Finance Research

Vol.8, No. 7, pp.42-79, July 2020

Published by ECRTD-UK

Print ISSN: 2053-4086(Print), Online ISSN: 2053-4094(Online)

Table 4.10 above presents the results on cross-sectional dependence of individuals in a panel series. The null hypothesis of no cross-sectional dependence (correlation) is tested against that of cross-sectional dependence. From the test statistics employed BreuschPagan LM, Pesaran scaled LM, Bias-corrected scaled LM and Pesaran CD it was evident that there is cross-sectional dependence in this variable. The $p$-value give a strong evidence against the null hypothesis. The interpretation is that some information in each of the cross-sections has the tendency to flow to other cross-sections.

Table 4.11 above presents the results on cross-sectional independence of individuals in a panel series. The null hypothesis of no cross-sectional dependence (correlation) is tested against that of cross-sectional dependence. From the test statistics employed in BreuschPagan LM, Pesaran scaled LM, Bias-corrected scaled LM and Pesaran CD, and it was evident that there is cross-sectional dependence in this variable. The p-value gave a strong evidence against the null hypothesis. The interpretation is that some information in each of the cross-sections tends to flow to other cross-sections

Multicollinearity Test / Correlation Test

Table 4.12 Pair-wise Correlation Test

\begin{tabular}{cccccc} 
& $\begin{array}{l}\text { Stock } \\
\text { Returns }\end{array}$ & $\begin{array}{c}\text { Investor } \\
\text { herd } \\
\text { behavior }\end{array}$ & $\begin{array}{c}\text { Investor } \\
\text { loss } \\
\text { aversion }\end{array}$ & $\begin{array}{c}\text { Investor } \\
\text { mental } \\
\text { accounting }\end{array}$ & $\begin{array}{c}\text { Investor } \\
\text { overconfidence }\end{array}$ \\
$\begin{array}{c}\text { Stock returns } \\
\text { Investor herd } \\
\text { behavior } \\
\begin{array}{c}\text { Investor loss } \\
\text { aversion }\end{array}\end{array}$ & -0.1480000 & 1.000000 & & & \\
$\begin{array}{c}\text { Investor mental } \\
\text { accounting } \\
\text { Investor }\end{array}$ & 0.035048 & 0.050570 & -0.026333 & 1.000000 & \\
overconfidence & 0.017307 & -0.038426 & -0.032091 & -0.054848 & 1.000000 \\
\hline
\end{tabular}

Table 4.12 shows the pair-wise correlation matrix. Brook (2002) asserts that multicollinearity is the problem that occurs when the explanatory variables are very highly correlated with each other. If there is no multicollinearity, then adding or removing a variable from a regression equation would not cause the values of the coefficients on the other variables to change. The result for pair-wise correlation shows that there is no muticollinearity problem since the highest correlation between the independent variables was $5.0570 \%$ between investor herd behavior and investor loss aversion and the least one was $-5.4848 \%$ between mental accounting and investor loss aversion. Thus, all the independent variables were retained for further analysis. 
European Journal of Accounting, Auditing and Finance Research

Vol.8, No. 7, pp.42-79, July 2020

Published by ECRTD-UK

Print ISSN: 2053-4086(Print), Online ISSN: 2053-4094(Online)

\section{Causality Tests}

Table 4.13 Granger Causality Test

Pairwise Granger Causality Tests

Lags: 4

\section{Null Hypothesis:}

Investor herding behavior does not

Granger Cause Stock Returns

Stock Returns does not Granger Cause

Investor Herding Behavior

Investor loss aversion does not Granger

Cause Stock Returns

Stock Returns does not Granger Cause

Investor Loss Aversion

Mental accounting does not Granger

Cause Stock Returns

Stock Returns does not Granger Cause

Investor Mental accounting

Investor overconfidence does not Granger

Cause Stock Returns

Stock Returns does not Granger Cause Investor

Overconfidence
Observations F-Statistic P-value

6156

2.77857

0.0254

7.60604

4.E-06

6108

61.8647

3.E-51

34.3290

2.E-28

6156

0.57503

0.6808

8.48472

8.E-07

6156

0.85898

0.4877

3.99537

0.0031

Table 4.13 above presents the results for granger causality. The table presents the results for the direction of causality between the dependent and the independent variables. The two-way causality results are presented in the appendices due to the large size of the table. Given the results all the p-values are statistically significant part from only two pairs; investor overconfidence does not granger cause stock market reactions and investor mental accounting does not granger cause stock returns. The interpretation was that a dynamic method that could handle lagged structure in the model was necessary. One of such a laborious model is the autoregressive distributed lag model (ARDL). Granger (1969) noted that, a variable $\mathrm{x}$ is said to granger-cause a variable $\mathrm{y}$ if, given the past values of $\mathrm{y}$, past values of $\mathrm{x}$ are useful for predicting $\mathrm{y}$. Failing to reject the null hypothesis is same as failing to reject the hypothesis that $\mathrm{x}$ does not granger-cause $\mathrm{y}$. 
European Journal of Accounting, Auditing and Finance Research

Vol.8, No. 7, pp.42-79, July 2020

Published by ECRTD-UK

Print ISSN: 2053-4086(Print), Online ISSN: 2053-4094(Online)

\section{Cointegration Test}

Table 4.14 Pedroni Cointegration Test

Series: Stock Returns, Investor Herd Behavior, Investor Loss Aversion, Investor

Mental Accounting and Investor Overconfidence

Null Hypothesis: No Cointegration

Alternative Hypothesis: Common AR coefficients (within-dimension)

\begin{tabular}{|c|c|c|c|c|}
\hline & $\underline{\text { Statistic }}$ & Prob. & $\begin{array}{c}\text { Weighted } \\
\text { Statistic }\end{array}$ & Prob. \\
\hline Panel V-Statistic & $-\overline{0.327263}$ & $\overline{0.6283}$ & $-\overline{4.508593}$ & $\overline{1.0000}$ \\
\hline Panel Rho-Statistic & -97.55195 & 0.0000 & -92.15360 & 0.0000 \\
\hline Panel PP-Statistic & -71.27764 & 0.0000 & -68.22089 & 0.0000 \\
\hline Panel ADF-Statistic & -42.10477 & 0.0000 & -41.06860 & 0.0000 \\
\hline
\end{tabular}

Alternative hypothesis: Individual AR coefficients (between-dimension)

$\begin{array}{lcc} & \underline{\text { Statistic }} & \underline{\text { Prob. }} \\ \text { Group Rho-Statistic } & -91.97357 & 0.0000 \\ \text { Group PP-Statistic } & -80.75326 & 0.0000 \\ \text { Group ADF-Statistic } & -46.70912 & 0.0000\end{array}$

Table 4.14 presents a set of Pedroni tests of a cointegrating vector. The table presents two sets of test statistics. The first part contains eight sets of test statistics under the null of homogeneity among all the panels. The word homogeneity meaning that the test of cointegration assume the data set as a single continuous structure and that all panels follow the same properties. These tests are namely; Panel v-Statistic, Panel Rho-Statistic Panel PP-Statistic and Panel ADF-Statistic. The second part of the table presents the test statistics under the assumption of heterogeneity. Heterogeneity here refers to the test of cointegration on each individual cross-section separately. These tests are namely; Group rho-Statistic, Group PP-Statistic and Group ADF-Statistic.

All the tests of cointegration in table 4.14 reject the null of no cointegration apart from only two as inferred by the p-values. Since most of the p-value had a value of zero, it was necessary to ensure that the techniques used for the model estimation considers the aspect of cointegration. The interpretation was that in this research study, cointegration was a key analytical tool.

\section{Regression Results}

This section presents the results of the regression of investor behaviour variables on stock returns. The section looks at the effect of herd behaviour on stock return in Kenya; effect of $r$ loss aversion on stock returns in Kenya; effect of mental accounting on stock returns in Kenya and effect of overconfidence on stock returns in Kenya. This were as indicated in chapter one as the objectives and hypotheses of the research. 
European Journal of Accounting, Auditing and Finance Research

Vol.8, No. 7, pp.42-79, July 2020

Published by ECRTD-UK

Print ISSN: 2053-4086(Print), Online ISSN: 2053-4094(Online)

Table 4.15 Group-mean Estimation (DOLS)

Dependent Variable: Stock Returns

\begin{tabular}{lrlrr}
\multicolumn{1}{c}{ Variable } & Coefficient & Std. Error & t-Statistic & P-value \\
$\quad$ & -0.019384 & 0.017982 & -1.077949 & 0.2811 \\
$\quad$ Investor herd Behavior & -0.080172 & 0.002033 & -39.43703 & 0.0000 \\
$\quad$ Investor loss Aversion & 0.067633 & 0.016382 & 4.128388 & 0.0000 \\
$\quad$ Investor Mental Accounting & -0.232056 & 0.062468 & -3.714797 & 0.0002 \\
$\quad$ & & & \\
$\quad$ Investor Overconfidence & 0.586706 & Mean dependent var & 0.204332 \\
& 0.565641 & S.D. dependent var & 12.01525 \\
R-squared & 7.918757 & Sum squared residual & 372791.4 \\
Adjusted R-squared & 34.96934 & &
\end{tabular}

Table 4.15 presents the results generated by employing the pooled estimation in the context of panel dynamic least square method. Pedroni (2001) extends the grouped estimator concept to DOLS estimation by averaging aver the individual cross-section DOLS estimates. This cointegration technique was purely developed to handle variables that are cointegrated of the same order in economics. However, in this research, all the variables were found to be integrated of order zero but never the less they were subjected to the same technique to bring out the difference between this traditional technique and the modern one that was primarily employed in this paper as the preference analytical tool. It assumes heterogeneity (independence of each crosssectional) in the data. It differs from the fully modified OLS in that it employs lead and lags in the estimation process. These leads and lags help to eliminate any asymptotic endogeneity and serial correlation.

The interesting finding was that the results are very close to the pooled mean group (which was the primary estimator) in this study. It is not surprising though since group mean estimation in (FMOLS) is already nested in pooled mean group. It was also of notable interest that using this alternative method all the variables retained their signs thus reinforcing the findings of the pooled mean group that is the primary procedure adopted in this paper.

\section{DISCUSSION}

\section{Herd Behavior}

From the regression results in table 4.15 above the long run coefficient of investor herding behavior was found to be -0.019384 . This value shows that holding other variables in the model constant, an increase in the investor behavior by one unit causes the market reaction to decrease by a value of -0.019384 units in Kenya. The negative effect shows that there is an inverse relationship between investor herd and stock returns. 
European Journal of Accounting, Auditing and Finance Research

Vol.8, No. 7, pp.42-79, July 2020

Published by ECRTD-UK

Print ISSN: 2053-4086(Print), Online ISSN: 2053-4094(Online)

The coefficient was also found to be statistically insignificant with a t-statistic value of 1.077949. In econometrics and statistical analysis, a t-statistic of 1.96 and above is normally accepted to be the threshold for significant. The standard error was found to be 0.017982 and the p-value was found to be 0.2811 . The interpretation was that in Kenya, the investor herd behavior has a statistically insignificant effect on stock market reaction in the long-run horizon. The findings indicate that investor herd behavior has no effect on stock returns in Kenya. The findings are consistent with rational asset pricing models and found no effect of herd behavior in the stock market in Portuguese stock market. However the findings are inconsistent with Vieira and Pereira (2015) who found herd behavior to have a negative and statistically significant effect in the stock market.

\section{Loss Aversion}

From the regression results in table 4.15 above the long run coefficient of investor loss aversion was found to be -0.080172 . This value shows that holding other variables in the model constant, an increase in the investor loss aversion by one unit causes the stock market reaction to decrease by a value of -0.080172 percent. The negative effect shows that there is an inverse relationship between investor loss aversion and stock market reaction.

The coefficient was also found to be statistically significant with a t-statistic value of 39.43703. In econometrics and statistical analysis, a t-statistic of 1.96 and above is normally accepted to be the threshold for significant. The standard error was found to be 0.002033 and the p-value was found to be 0.0000 . The interpretation was that in Kenya the investor loss aversion has a statistically significant effect on stock market reaction in the long-run horizon. This imply that increase in loss aversion would cause a reduction market reaction. These findings contradict those of Genesove and Mayer (2001), who found that the loss aversion had positive effect on stock market reaction when considered to enter the model linearly and negative when raised to the second power.

\section{Mental Accounting}

From the regression results in table 4.15 above the long run coefficient of investor mental accounting was found to be 0.067633. This value shows that holding other variables in the model constant, an increase in the Investor loss aversion by one unit causes the market reaction to increase by a value of 0.067633 . The positive effect shows that investors views the companies that pay less divided as the ones that will have a high return in the future thus these stocks would be termed as more viable.

The coefficient was also found to be statistically significant with a t-statistic value of 4.128388. In econometrics and statistical analysis, a t-statistic of 1.96 and above is normally accepted to be the threshold for statistical significance. The standard error was found to be 0.016382 and the p-value was found to be 0.0000 . The interpretation was that in Kenya investor mental accounting has a statistically significant effect on stock market reaction in the long-run horizon. This imply that increase in loss aversion would cause an increase in market reaction. These findings support those of Barberis and Huang (2001) who found that the portfolio formed to mimic the effect of investor mental 
European Journal of Accounting, Auditing and Finance Research

Vol.8, No. 7, pp.42-79, July 2020

Published by ECRTD-UK

Print ISSN: 2053-4086(Print), Online ISSN: 2053-4094(Online)

accounting had have a positive effect on stock market reaction. The interpretation was that the firms that pay less divided can subsequently beat those that pay high divided in an attempt to attract investors. The findings of this research also support the views of Miller and Modigliani (1961) who argued that divided does not really reflect the value of the firm since the management might increase dividend payout just to manipulate the investors into buying more of the firm's shares even when the actual net worth of the firm is not desirable.

\section{Overconfidence}

From the regression results in table 4.15 above the long run coefficient of Investor overconfidence was found to be -0.232056 . This value shows that holding other variables in the model constant, an increase in the Investor overconfidence by one percent causes the abnormal stock return to increase by a value of -0.232056 percent. The negative effect shows that there is a direct relationship between Investor overconfidence and stock returns.

The coefficient was also found to be statistically significant with a t-statistic value of 3.714797. In econometrics and statistical analysis, a t-statistic of 1.96 and above is normally accepted to be the threshold for statistical significance. The standard error was found to be 0.062468 and the p-value was found to be 0.0002 . The interpretation was that in Kenya the Investor overconfidence has a statistically significant effect on market reaction in the long-run horizon. This implies that increase in investor overconfidence would cause an increase in market reaction. These findings are consistent those of Metwally and Darwish (2015) where the investor overconfidence had a positive and statistically significant effect on stock market reaction. Tariq and Ullah (2013) was also consistent because they found a positive effect of investor overconfidence on stock return hence consistent with the results in this study.

\section{Hypothesis of Rationality}

Hypothesis One Test

Table 4.16 H01: Investor herd behaviour has no significant effect on stock returns in Kenya

\begin{tabular}{lccc} 
Wald Test: & Value & $\mathrm{df}$ & Probability \\
Test Statistic & -1.077949 & 5945 & 0.2811 \\
t-statistic & 1.161973 & $(1,5945)$ & 0.2811 \\
F-statistic & 1.161973 & 1 & 0.2811 \\
Chi-square & & & \\
Null Hypothesis: C(1)=0 & & \\
Null Hypothesis Summary: & & Value & Std. Err. \\
Normalized Restriction (=0) & -0.019384 & 0.017982 \\
C(1) & & \\
Restrictions are linear in coefficients. & & & \\
\hline
\end{tabular}

Table 4.16 presents the results for the ward test of hypothesis one. The three test 
European Journal of Accounting, Auditing and Finance Research

Vol.8, No. 7, pp.42-79, July 2020

Published by ECRTD-UK

Print ISSN: 2053-4086(Print), Online ISSN: 2053-4094(Online)

statistics are t-statistic-1.077949, F-statistic 1.161973 and Chi-square 1.161973. These values are statistically insignificant as showed by p-values of $0.2811,0.2811$ and 0.2811 respectively. The null hypothesis of the coefficient being zero $(\mathrm{C}(1)=0)$ is not rejected. The interpretation is that the individual effect of investor heard behavior is statistically insignificant. In other word investor herd behavior contribute very little to the stock return.

Hypothesis Two Test

Table 4.17 H02: Investor loss aversion has no significant effect on stock market reactions in Kenya.

\begin{tabular}{lccc}
\hline Wald Test: & & & \\
Test Statistic & Value & df & Probability \\
t-statistic & -39.43703 & 5945 & 0.0000 \\
F-statistic & 1555.280 & $(1,5945)$ & 0.0000 \\
Chi-square & 1555.280 & 1 & 0.0000 \\
Null Hypothesis: C(2)=0 & & & \\
Null Hypothesis Summary: & & Value & Std. Err. \\
Normalized Restriction (=0) & & \\
C(2) & & -0.080172 & 0.002033 \\
Restrictions are linear in coefficients. & & \\
\hline
\end{tabular}

Table 4.18 presents the results for the ward test of hypothesis one. The three test statistics are t-statistic-39.43703, F-statistic 1555.280 and Chi-square 1555.280. These values are statistically significant as showed by p-values of $0.0000,0.0000$ and 0.0000 respectively. The null hypothesis of the coefficient being zero $(C(2)=0)$ is rejected. The interpretation is that the individual effect of investor loss aversion is statistically significant. In other word investor loss aversion contribute very significantly to the stock return.

\section{Hypothesis Three Test}

Table 4.19 Ho3: Investor mental accounting has no significant effect on stock return in Kenya.

\begin{tabular}{|c|c|c|c|}
\hline \multicolumn{4}{|l|}{ Wald Test: } \\
\hline Test Statistic & Value & $\begin{array}{l}\text { Degrees of } \\
\text { freedom }\end{array}$ & Probability \\
\hline t-statistic & 4.128388 & 5945 & 0.0000 \\
\hline F-statistic & 17.04358 & $(1,5945)$ & 0.0000 \\
\hline Chi-square & 17.04358 & 1 & 0.0000 \\
\hline \multicolumn{4}{|l|}{$\begin{array}{l}\text { Null Hypothesis: } C(3)=0 \\
\text { Null Hypothesis Summary: }\end{array}$} \\
\hline Normalized Restriction $(=0)$ & & Value & Std. Err. \\
\hline$C(3)$ & & 0.067633 & 0.016382 \\
\hline
\end{tabular}


European Journal of Accounting, Auditing and Finance Research

Vol.8, No. 7, pp.42-79, July 2020

Published by ECRTD-UK

Print ISSN: 2053-4086(Print), Online ISSN: 2053-4094(Online)

Table 4.19 presents the results for the ward test of hypothesis one. The three test statistics are t-statistic 4.128388, F-statistic 17.04358 and Chi-square 17.04358. These values are statistically significant as showed by p-values of $0.0000,0.0000$ and 0.0000 respectively. The null hypothesis of the coefficient being zero $(C(3)=0)$ is rejected. The interpretation is that the individual effect of investor mental accounting is statistically significant. In other word investor mental accounting contribute very significantly to stock return.

\section{Hypothesis Four Test}

Table 4.20 H04: Investor overconfidence has no significant effect on stock return of listed companies in Kenya.

Wald Test:

Test Statistic

t-statistic

F-statistic

Chi-square

Null Hypothesis: $C(4)=0$

Null Hypothesis Summary:

Normalized Restriction $(=0)$

$\mathrm{C}(4)$

Restrictions are linear in coefficients.
Value

$-3.714797$

13.79972

13.79972
Degrees of freedom

5945

$(1,5945)$

1

Value

$-0.232056$
Probability

0.0002

0.0002

0.0002

Table 4.20 presents the results for the ward test of hypothesis one. The three test statistics are t-statistic-3.714797, F-statistic 13.79972 and Chi-square 13.79972. These values are statistically significant as showed by p-values of respectively $0.0002,0.0002$ and 0.0002. The null hypothesis of the coefficient being zero $(C(4)=0)$ is rejected. The interpretation is that the individual effect of investor overconfidence is statistically significant. In other word investor overconfidence contribute very significantly to the stock return.

\section{Post Estimation Tests}

Table 4.21 Model Residuals Unit Root Test

$\begin{array}{lcccc}\begin{array}{l}\text { Method } \\ \text { Null: Unit root (assumes common unit root process) }\end{array} & \text { P-value } & \begin{array}{c}\text { Cross- } \\ \text { sections }\end{array} & \text { Observation } \\ \text { Levin, Lin \& Chu t* } & -85.9078 & 0.0000 & 48 & 6196 \\ & & & & \\ \text { Null: Unit root (assumes individual unit root process) } & -78.1312 & 0.0000 & 48 & 6196 \\ \text { Im, Pesaran and Shin W-stat } & 3351.68 & 0.0000 & 48 & 6196 \\ \text { ADF - Fisher Chi-square } & 3432.83 & 0.0000 & 48 & 6201 \\ \text { PP - Fisher Chi-square } & & \end{array}$

Table 4.21 presents the results on the unit root test of the residuals after the model estimation. From the results, it was clear that the residuals were stationary since the nulls 
European Journal of Accounting, Auditing and Finance Research

Vol.8, No. 7, pp.42-79, July 2020

Published by ECRTD-UK

Print ISSN: 2053-4086(Print), Online ISSN: 2053-4094(Online)

of unit root both under common root process and individual unit root process test were rejected. This argument is reinforced by the p-values. The interpretation was that the model was optimally identified.

\section{IMPLICATION TO RESEARCH AND PRACTICE}

The study contributes to existing literature of behavioural finance in financial markets. The study draws attention to the measures of investor behaviour variables: herd behaviour, loss aversion, mental accounting and overconfidence and its effect on stock return in Kenya. The results in this study shows that investor behaviour variables i.e. herd behaviour, loss aversion, and overconfidence had a significant effect on stock return i.e. results in abnormal returns of listed stocks in Kenya. However, mental accounting had an insignificant effect on stock return in Kenya.

The study shows how herd behavior variable's effect on stock prices moving from its fundamental values causing abnormal returns hence stock market reaction resulting from to variations in returns. The results of study contribute to literature on how investors and stock brokers should asses herd behavior variable at NSE to determine effect on stock market reaction in Kenya. Herd behaviour variable had positive significant effect on stocks returns at the NSE. The literature indicated that investors should know the estimates of intrinsic values of stocks in order to make informed investment decisions.

The study also contributes to literature on how loss aversion variable caused an effect on stock return in Kenya. It showed how investors could exploit bubbles and avoid the risk of incurring losses in their stock investments. Loss aversion caused stock prices moving from their fundamental values leading to abnormal returns hence stock market reaction resulting in variations of returns. In this research, it was revealed that loss aversion had significant effect on stock market reaction. It was noted that the loss aversion variable had a negative significant effect on stock market reaction which meant that it led to abnormal returns in the stock market. Since the influence of loss aversion was supported by all the results from RE model had a negative significant effect. Investors and stock brokers should assess the effect of loss aversion variable when making investment decisions to ascertain whether how prices of listed stock moved away from its fundamental values.

The study contributes to literature on how mental accounting variable measure causes an insignificant effect on stock return in Kenya. Mental accounting variable did not cause abnormal returns. There was no stock market reaction resulting from to variations in returns while analyzing the measure of mental accounting variable. Mental accounting variable did not lead to stock prices moving from its fundamental values. In this research, it was revealed that mental accounting variable had an insignificant effect on stock market reaction. It was noted that the mental accounting did not cause abnormal returns at NSE.

The study contributes to literature on how overconfidence variable causes a significant effect on the stock market reaction at NSE. Overconfidence variable caused stock prices to move away from its fundamental values resulting in abnormal returns hence stock 
European Journal of Accounting, Auditing and Finance Research

Vol.8, No. 7, pp.42-79, July 2020

Published by ECRTD-UK

Print ISSN: 2053-4086(Print), Online ISSN: 2053-4094(Online)

market reaction because of variations in returns. In this research, it was revealed that overconfidence variable had a negative significant effect on stock market reaction. It was noted that overconfidence variable could cause abnormal returns at NSE. Investors and stock brokers should assess the effect of overconfidence variable when making investment decisions to ascertain whether the prices of equities had moved away from the fundamental values

\section{CONCLUSION}

The study concluded that in the NSE, Kenyan stock market, the investor herd behavior has a no significant effect on stock market reaction. The study concludes that the herd behavior has statistically insignificant effect on stock returns. This variable was insignificant in the primary model that uses the pooled mean group as an estimator as well as the other two techniques that considers the pooling and the group aspect separately.

This variable was only significant in only one of the five regressions that were ran to reveal the dynamics of the effect of investor behavior on stock returns. This shows that investors may remain silent at times and withhold trading even when the other investors are sharing information that might trigger trading. In extension, though this variable has a statistically insignificant effect it should be retained since statistical significance and economic significance are different.

The study concludes that in Kenyan stock market, the investor loss aversion has a significant effect on stock returns. The study concludes that the investor loss aversion has a statistically significant effect on stock returns. This variable was significant in the primary model that uses the pooled mean group as an estimator as well as the other two techniques that considers the pooling and the group aspect separately.

This variable was significant in all the five regressions that were ran to reveal the dynamics of the effect of the investor loss aversion on stock returns. This showed that investors are concerned about the losses or gains in their investment decisions in Kenya which results in stock returns.

The study concluded that in Kenyan stock market, the investor mental accounting has a significant effect on stock returns. The study concludes that the investor mental accounting has a statistically significant effect on stock returns. This variable was significant in the primary model that used the pooled mean group as the estimator as well as the other two techniques that considers the pooling and the group aspect separately.

This variable was significant in all the five regressions that were ran to reveal the dynamics of the effect of the investor mental accounting on stock returns. This showed that investors are concerned about the divided announcement by the listed companies and that they are likely to make investment decisions in securities in Kenya based on divided information. 
European Journal of Accounting, Auditing and Finance Research

Vol.8, No. 7, pp.42-79, July 2020

Published by ECRTD-UK

Print ISSN: 2053-4086(Print), Online ISSN: 2053-4094(Online)

The study concluded that in Kenyan stock market, investor overconfidence bias has a significant effect on stock returns. The study concludes that the investor overconfidence has a statistically significant effect on stock returns. This variable was significant in the primary model that used the pooled mean group as an estimator as well as the other two techniques that consider the pooling and the group aspect separately.

This variable was statistically significant in all the five regressions that were ran to reveal the dynamics of the effect of the investor overconfidence on stock market reaction. This shows that investors are likely to purchase more stocks in the market when they are overconfident. Overconfidence therefore causes stock returns in Kenya.

\section{FUTURE RESEARCH}

Most studies done on the securities market were inconclusive especially how behavioural factors influenced returns in the developing market. To give a meaningful conclusion about behavioural factors and the developing market, the research suggested the following areas for research. Investor behaviour of the NSE around the other East African countries securities market returns could be studied to see if instead of the NSE herding around developed markets it was herding on the performance of the neighboring countries. The magnitude of investor behaviour at the NSE as the market efficiency improves should be studied. The relationship between Nairobi securities exchange efficiency and economic growth can also be studied.

The study mapped previously studied variable of pricing error into the observable measures of mispricing and price overreaction. Prices react to investor behavior in our model because Kenyan investors herd, practiced mental accounting, were loss averse and overconfident. This research discussed only four (4) behavioural variables with explanation power on stock return in Kenya. This was evident from the pooled, fixed effect and random effect models that showed that the model explained approximately $66 \%$ on the variation of the stock return. It is therefore in this context that the future researchers are encouraged to consider other irrational investor behavior variables caused stock market reaction to increase the predictive capability of the model. Other investor behavioural variables should be studied to determine the effect on stock return in Kenya.

Event study should be used to analyze the change in expected and actual earnings of listed companies. Neuroeconomics research on brain activity of economics and behavioral psychology to study how the brain affects financial decisions should also be the next area of further research. The investor's guide to spotting the signs of a stock market crash should be studied. Other areas of research are the effects of social economic and political changes in a country on investor behavior and how macroeconomic factors affect stock pricing models at the Nairobi Securities Exchange. 
European Journal of Accounting, Auditing and Finance Research

Vol.8, No. 7, pp.42-79, July 2020

Published by ECRTD-UK

Print ISSN: 2053-4086(Print), Online ISSN: 2053-4094(Online)

\section{REFERENCES}

Abdellaoui, M., Bleichrodt, H., \& Paraschiv, C. (2007). Loss aversion under prospect theory: A parameter-free measurement. Management Science, 53(10), 16591674.

Adel, B., \& Mariem, T. (2013). The Impact of Overconfidence on Investors' Decisions. Business and Economic Research, 3(2), 53.

Aduda, J., \& Muimi, P. (2011). Test for investor rationality for companies listed at the Nairobi Stock Exchange. Journal of Modern accounting and auditing, 7(8), 827.

Barber, B. M., \& Odean, T. (2001). Boys will be boys: Gender, overconfidence, and common stock investment. Quarterly journal of Economics, 261-292.

Barberis, N. C. (2013). Thirty years of prospect theory in economics: A review and assessment. The Journal of Economic Perspectives, 27(1), 173-195.

Barberis, N., \& Huang, M. (2001). Mental accounting, loss aversion, and individual stock returns. The Journal of Finance, 56(4), 1247-1292.

Barberis, N., Huang, M., \& Santos, T. (1999). Prospect theory and asset prices (No. w7220). National bureau of economic research.

Barberis, N., Shleifer, A., \& Vishny, R. (1998). A model of investor sentiment. Journal of financial economics, 49(3), 307-343.

Benartzi, S., \& Thaler, R. H. (1995). Myopic loss aversion and the equity premium puzzle. The quarterly journal of Economics, 110(1), 73-92.

Bernoulli, J. (1713). Ars conjectandi. Impensis Thurnisiorum, fratrum.

Bhattacharya, N., \& Garrett, T. A. (2008). Why people choose negative expected return assets-an empirical examination of a utility theoretic explanation. Applied Economics, 40(1), 27-34.

Biais, B., Hilton, D., Mazurier, K., \& Pouget, S. (2005). Judgemental overconfidence, self-monitoring, and trading performance in an experimental financial market. The Review of economic studies, 72(2), 287-312.

Blasco, N., Corredor, P., \& Ferreruela, S. (2012) The Implications of Herding on Volatility. The Case of the Spanish Stock Market Quantitative Finance, 12(2), 311-327.

Blasco, N., Corredor, P., \& Ferreruela, S. (2012). Does herding affect volatility? Implications for the Spanish stock market. Quantitative Finance, 12(2), 311-327.

Bond, S. A., \& Satchell, S. E. (2006). Asymmetry, loss aversion, and forecasting. The Journal of Business, 79(4), 1809-1830.

Boussaidi, R. (2013). Overconfidence Bias and Overreaction to Private Information Signals: The Case of Tunisia. Procedia-Social and Behavioral Sciences, 81, 241245.

Brenner, L., Rottenstreich, Y., Sood, S., \& Bilgin, B. (2007). On the psychology of loss aversion: Possession, valence, and reversals of the endowment effect. Journal of Consumer Research, 34(3), 369-376. 
European Journal of Accounting, Auditing and Finance Research

Vol.8, No. 7, pp.42-79, July 2020

Published by ECRTD-UK

Print ISSN: 2053-4086(Print), Online ISSN: 2053-4094(Online)

Boussaidi, R. (2017). The winner-loser effect in the Tunisian stock market: A multidimensional risk-based explanation. Borsa Istanbul Review.

Buchak, L. (2014). Risk and tradeoffs. Erkenntnis, 79(6), 1091-1117.

Caplin, A., \& Leahy, J. (2001). Psychological expected utility theory and anticipatory feelings. Quarterly Journal of economics, 55-79.

Choi, I. (2001). "Unit root Tests for Panel Data," Journal of International Money and Finance, 20: 249-272.

Chiang, T. C., \& Zheng, D. (2010). An empirical analysis of herd behavior in global stock markets. Journal of Banking \& Finance, 34(8)

Daniel, K., \& Hirshleifer, D. (2015). Overconfident investors, predictable returns, and excessive trading. The Journal of Economic Perspectives, 29(4), 61-87.

Daniel, K., Hirshleifer, D., \& Subrahmanyam, A. (1998). Investor psychology and security market under-and overreactions. the Journal of Finance, 53(6), 18391885.

Daniel, K. D., Hirshleifer, D., \& Subrahmanyam, A. (2001). Overconfidence, arbitrage, and equilibrium asset pricing. The Journal of Finance, 56(3), 921-965.

Daniel, K., \& Titman, S. (1999). Market efficiency in an irrational world. Financial Analysts Journal, 55(6), 28-40.

De Bondt, W. F., \& Thaler, R. (1985). Does the stock market overreact? The Journal of finance, 40(3), 793-805.

De Long, J. B., Shleifer, A., Summers, L. H., \& Waldmann, R. J. (1990). Positive feedback investment strategies and destabilizing rational speculation. the Journal of Finance, 45(2), 379-395.

DeLong, J. B. (2005). Financial Markets, Noise Traders, and Fundamental Risk: Background Memo.

Dreman, D. N., \& Lufkin, E. A. (2000). Investor overreaction: evidence that its basis is psychological. The Journal of Psychology and Financial Markets, 1(1), 61-75.

Durand, R., Newby, R., Tant, K., \& Trepongkaruna, S. (2013). Overconfidence, overreaction and personality. Review of Behavioral Finance, 5(2), 104-133.

Ed Easley, D., \& Yang, L. (2015). Loss aversion, survival and asset prices. Journal of Economic Theory, 160, 494-516.wards, W. (1968). Conservatism in human information processing. Formal representation of human judgment, 17, 51.

Fama, E. F. (1970). Multi-period consumption-investment decisions. The American Economic Review, 60(1), 163-174.

Farag, H. (2014). Investor overreaction and unobservable portfolios: evidence from an emerging market. Applied Financial Economics, 24(20), 1313-1322.

Fennema, H., \& Wakker, P. (1997). Original and cumulative prospect theory: A discussion of empirical differences. Journal of Behavioral Decision Making, 10, 53-64. 
European Journal of Accounting, Auditing and Finance Research

Vol.8, No. 7, pp.42-79, July 2020

Published by ECRTD-UK

Print ISSN: 2053-4086(Print), Online ISSN: 2053-4094(Online)

Fischer, D. (2012). Investor Underreaction to Earnings Surprises and Overreaction to Product News in the Drug Industry. The Journal of Business and Economic Studies, 18(2), 82.

Friedman, M., \& Savage, L. J. (1948). The utility analysis of choices involving risk. The journal of political economy, 279-304.

Frydman, C., Hartzmark, S. M., \& Solomon, D. H. (2015). Rolling mental accounts. Available at SSRN.

$\mathrm{Fu}, \mathrm{T}$. (2010). Herding in China equity market. International journal of economics and finance, 2(2), 148.

Gächter, S., Johnson, E. J., \& Herrmann, A. (2007). Individual-level loss aversion in riskless and risky choices. IZA Discussion Paper No. 2961. Retrieved from anonftp.iza.org

Glaser, M., \& Weber, M. (2007). Overconfidence and trading volume. The Geneva Risk and Insurance Review, 32(1), 1-36.

Grinblatt, M., \& Han, B. (2005). Prospect theory, mental accounting and momentum. Journal of financial economics, 78(2), 311-339.

Han, C., Hwang, S., \& Ryu, D. (2015). Market overreaction and investment strategies. Applied Economics, 47(54), 5868-5885.

Harinck, F., Van Beest, I., Van Dijk, E., \& Van Zeeland, M. (2012). Measurementinduced focusing and the magnitude of loss aversion: The difference between comparing gains to losses and losses to gains. Judgment and Decision Making, $7(4), 462$.

Hartley, R., \& Farrell, L. (2002). Can expected utility theory explain gambling?. The American Economic Review, 92(3), 613-624.

Heath, T. B., Chatterjee, S., \& France, K. R. (1995). Mental accounting and changes in price: The frame dependence of reference dependence. Journal of Consumer Research, 22(1), 90-97.

Huisman, R., van der Sar, N. L., \& Zwinkels, R. C. (2012). A new measurement method of investor overconfidence. Economics Letters, 114(1), 69-71.

Im, K. S., M. H. Pesaran, and Y. Shin (2003). "Testing for Unit Roots in Heterogeneous Panels," Journal of Econometrics, 115, 53-74.

Jarrow, R., \& Zhao, F. (2006). Downside loss aversion and portfolio management. Management Science, 52(4), 558-566.

Jegadeesh, N., \& Titman, S. (1993). Returns to buying winners and selling losers: Implications for stock market efficiency. The Journal of finance,48(1), 65-91.

Jlassi, M., Naoui, K., \& Mansour, W. (2014). Overconfidence behavior and dynamic market volatility: evidence from international data. Procedia Economics and Finance, 13, 128-142. 
European Journal of Accounting, Auditing and Finance Research

Vol.8, No. 7, pp.42-79, July 2020

Published by ECRTD-UK

Print ISSN: 2053-4086(Print), Online ISSN: 2053-4094(Online)

Kahneman, D., \& Tversky, A. (1979). Prospect theory: An analysis of decision under risk. Econometrica: Journal of the Econometric Society, 263-291.

Kahneman, D., \& Tversky, A. (1982). Variants of uncertainty. Cognition, 11(2), 143157.

Khan, H., Hassairi, S. A., \& Viviani, J. L. (2011). Herd behavior and market stress: the case of four European countries. International Business Research, 4(3), 53.

Keim, D. B. (1985). Dividend yields and stock returns: Implications of abnormal January returns. Journal of Financial Economics, 14(3), 473-489.

Ko, K. J., \& Huang, Z. J. (2007). Arrogance can be a virtue: Overconfidence, information acquisition, and market efficiency. Journal of Financial Economics, 84(2), 529-560.

Kumar, A., \& Lim, S. S. (2008). How do decision frames influence the stock investment choices of individual investors? Management science, 54(6), 1052-1064.

Lee, S., \& Lee, K. (2015). Heterogeneous expectations leading to bubbles and crashes in asset markets: tipping point, herding behavior and group effect in an agent-based model. Journal of Open Innovation: Technology, Market, and Complexity, 1(1), 1.

Levin, A., C. F. Lin, and C. Chu (2002). "Unit Root Tests in Panel Data: Asymptotic and Finite-Sample Properties," Journal of Econometrics, 108, 1-24.

Levy, J. S. (1997). Prospect theory and the cognitive-rational debate. Decisionmaking on war and peace: The cognitive-rational debate, 33-50.

Lin, S. (2010). Gradual Information Diffusion and Asset Price Momentum (No. 10-04).

Lux, T. (1995). Herd behaviour, bubbles and crashes. The economic journal, 881-896.

Maddala, G. S. and Shaowen Wu (1999). "A Comparative Study of Unit Root Tests with Panels Data and a New Simple Test," Oxford Bulletin of Economics and Statistics, 61, 631-652.

Metwally, A. H., \& Darwish, O. (2015). Evidence of the overconfidence bias in the Egyptian stock market in different market states. The Business \& Management Review, 6(4), 178.

Mbaluka, P. K. (2008). Behavioral effects on individuals' decision-Making process using the prospect theory: A Case of investors at the NSE (Doctoral dissertation, University Of Nairobi, School of Business).

Messis, P., \& Zapranis, A. (2014). Herding behaviour and volatility in the Athens Stock Exchange. The Journal of Risk Finance, 15(5), 572-590.

Mobarek, A., Mollah, S., \& Keasey, K. (2014). A cross-country analysis of herd behavior in Europe. Journal of International Financial Markets, Institutions and Money, 32, 107-127. 
European Journal of Accounting, Auditing and Finance Research

Vol.8, No. 7, pp.42-79, July 2020

Published by ECRTD-UK

Print ISSN: 2053-4086(Print), Online ISSN: 2053-4094(Online)

Neumann, J. V. (1944). Morgenstern, 1944. Theory of games and economic behavior.

Park, C. (2010). When does the dividend-price ratio predict stock returns? Journal of Empirical Finance, 17(1), 81-101.

Parkinson, M. (1980). The extreme value method for estimating the variance of the rate of return. Journal of Business, 61-65.

Pedroni, P. (2001). Purchasing power parity tests in cointegrated panels. The review of Economics and Statistics, 83(4), 727-731.

Pesaran, M. H., Shin, Y., \& Smith, R. P. (1999). Pooled mean group estimation of dynamic heterogeneous panels. Journal of the American Statistical Association, 94(446), 621-634.

Pettigrew, R. (2015). Risk, rationality and expected utility theory. Canadian Journal of Philosophy, 45(5-6), 798-826.

Popescu, D., (2008). Behaviour finance, technical analysis defined and their relationships. Paper presented to the Montreal CFA, May 21, 2008

Ramiah, V., Xu, X., \& Moosa, I. A. (2015). Neoclassical finance, behavioral finance and noise traders: A review and assessment of the literature. International Review of Financial Analysis, 41, 89-100.

Statman, M., Thorley, S., \& Vorkink, K. (2006). Investor overconfidence and trading volume. Review of Financial Studies, 19(4), 1531-1565.

Scott, J., Stumpp, M., \& Xu, P. (2003). Overconfidence bias in international stock prices. The journal of portfolio management, 29(2), 80-89.

Shefrin, H., \& Statman, M. (2011). Behavioral finance in the financial crisis: Market efficiency, Minsky, and Keynes. Santa Clara University, November.

Soares, J. V., \& Serra, A. P. (2005). Overreaction and Underreaction: Evidence for the Portuguese stock market. Faculdade de Economia da Universidadedo Porto.November.

Tariq, B., \& Ullah, N. (2013). Investor Overconfidence and Stock Returns: Evidence from Pakistan. IOSR Journal of Business and Management 8 (1), 77-84

Thaler, R. (1985). Mental accounting and consumer choice. Marketing science, 4(3), 199-214.

Thaler, R. H. (Ed.). (2005). Advances in behavioral finance (Vol. 2). Princeton University Press.

Thaler, R. H., \& Johnson, E. J. (1990). Gambling with the house money and trying to break even: The effects of prior outcomes on risky choice. Management science, 36(6), 643-660.

Thirikwa, G. M., \& Olweny, T. (2015). Determinants of herding in the nairobi securities exchange Economics and Finance Review 4(05). 14 - 30 retreived from http://www.businessjournalz.org/efr/

Tversky, A. and D. Kahneman, (1974), "Judgments under Uncertainty: Heuristics and Biases," Science pp. 1124-1131. 
European Journal of Accounting, Auditing and Finance Research

Vol.8, No. 7, pp.42-79, July 2020

Published by ECRTD-UK

Print ISSN: 2053-4086(Print), Online ISSN: 2053-4094(Online)

Uygur, U., \& Taş, O. (2014). The impacts of investor sentiment on returns and conditional volatility of international stock markets. Quality \& Quantity, 48(3), 1165-1179.

Vieira, E. F. S., \& Pereira, M. S. V. (2015). Herding behaviour and sentiment: Evidence in a small European market. Revista de Contabilidad, 18(1), 78-86.

Wan, D., Cheng, K., \& Yang, X. (2014). The reverse volatility asymmetry in Chinese financial market. Applied financial economics, 24(24), 1555-1575.

Werah, A. O. (2006). A survey of the influence of Behaviourial Factors on Investor activities at the Nairobi Stock Exchange (Doctoral dissertation).

Yeoh, L. Y., \& Wood, A. (2011). Overconfidence, Competence and Trading Activity. Working paper. Retrieved, from http://www.cass.city.ac. uk/_data/assets/pdf_file/0006/79152/Wood.pdf.

You, H., \& Zhang, X. J. (2011). Limited attention and stock price drift following earnings announcements and 10-K filings. China Finance Review International, 1(4), 358-387.

Zaiane, S., \& Abaoub, E. (2009). Investor overconfidence and trading volume: the case of an emergent market. International Review of Business Research Papers, 5(0), 213-222. 